\title{
The Characteristics of Non-Diabetic Mothers with Macrosomic Newborns
}

\section{Makrozomik Bebek Doğuran Diyabeti Olmayan Annelerin Özellikleri}

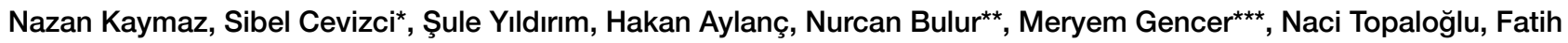

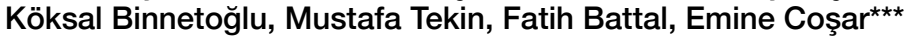

\author{
Çanakkale Onsekiz Mart University Faculty of Medicine, Department of Child Health and Diseases, Çanakkale, Turkey \\ *Çanakkale Onsekiz Mart University Faculty of Medicine, Department of Public Health, Çanakkale, Turkey \\ ${ }^{\star *}$ Mardin Maternity and Children's Hospital, Clinic of Child Health and Diseases, Mardin, Turkey \\ ${ }^{\star \star \star}$ Çanakkale Onsekiz Mart University Faculty of Medicine, Department of Obstetrics and Gynecology, Çanakkale, Turkey
}

Keywords

Newborn, birth weight, macrosomia,

healthy pregnancy

\section{Anahtar kelimeler \\ Yenidoğan, doğum ağırlığı, makrozomi, sağlıklı gebelik}

Received/Geliş Tarihi : 20.08.2014

Accepted/Kabul Tarihi : 23.02 .2016

DOI: $10.4274 /$ jcp. 44154

Address for Correspondence/Yazışma Adresi: Şule Yıldırım MD, Çanakkale Onsekiz Mart University Faculty of Medicine, Department of Child Health and Diseases,

Çanakkale, Turkey

Phone: +90 5058280707

E-mail: sulesln@yahoo.com

(C) The Journal of Current Pediatrics, published by Galenos Publishing. (c) Güncel Pediatri Dergisi, Galenos Yayınevi tarafından basılmıștır.

\begin{abstract}
Introduction: Fetal macrosomia is a condition with heterogeneous etiologic factors and its' frequency is increasing in recent years. Many macrosomic infants are born without any risk factors and accurate prediction of macrosomia is not possible with only single risk factor. The aim of this study was to research the characteristics of healthy mothers without diabetes who gave birth to macrosomic infants.

Materials and Methods: This case-control study comprised 291 healthy pregnant women who were monitored and delivered at Mardin Women and Children's Hospital. Inclusion criteria were (a) no disease or conditions that may affect birth weight, (b) normal healthy pregnancy and (c) singleton live infants born between 37-42 weeks with no structural defects. A birth weight above $4.000 \mathrm{~g}$ was defined as macrosomic neonate. The study group was divided in two; group 1 had a birth weight less than $4.000 \mathrm{~g}$ and group 2 had a birth weight above $4.000 \mathrm{~g}$. Characteristics of mother and newborn were analyzed to determine any association with macrosomia.

Results: The logistic regression analysis results indicated that the risk of macrosomic infant were male gender of the infant [odds ratio (OR): 3.39; $95 \%$ confidence interval (CI): 2.010-5.211; $<<0.001]$, maternal age being above 35 years (OR: $2.25 ; 95 \% \mathrm{CI}: 1.919-4.005 ; \mathrm{p}=0.026)$ and duration of gestation being above 40 weeks (OR: 1.72; 95\% CI: 1.103-2.949; $\mathrm{p}=0.009$ ).

Conclusions: There are various factors behind having a macrosomic infant in the absence of glucose intolerance.These risk factors should be taken into consideration for possible complication of macrosomia and mothers with the risk factors should be informed.
\end{abstract}

$\ddot{O} \mathbf{z}$

Giriş: Fetal makrozomi heterojen etiyolojik faktörlere sahip bir durumdur ve sıklığı son yıllarda giderek artmaktadır. Birçok makrozomik bebek belli bir risk faktörü olmaksızın doğar ve makrozominin doğru tahmini tek bir risk faktörü ile öngörülemez. Bu çalışmanın amacı makrozomik bebek doğuran diyabeti olmayan sağlıklı annelerin özelliklerini araştırmaktır.

Gereç ve Yöntem: Bu olgu-kontrol çalışması Mardin Kadın Doğum ve Çocuk Hastanesi'nde izlenmiş ve doğum yapmış 291 sağlıklı gebe kadından oluşmaktadır. Çalışmaya dahil edilme kriterleri (a) doğum ağırlığını etkileyecek hastalık veya 
durum olmaması, (b) normal sağlıklı gebelik ve (c) 37-42 hafta arası yapısal defekti olmayan tekiz bebek doğurma idi. Dört bin gr üzeri doğum ağırlığı makrozomi olarak tanımlandı. Çalışma grubu ikiye ayrıldı; grup 1 4,000 gr altı doğum ağırlığı ve grup 2 4,000 gr üzeri doğum ağırlığı. Anne ve bebek özelliklerinin makrozomi ile ilişkisi olup olmadığı incelendi.

Bulgular: Lojistik regresyon analizi sonuçlarına göre makrozomik bebek sahibi olma riskleri erkek cinsiyet [odds oranı (OR) $3,39, \% 95$ güven aralığ (GA): 2,010-5,211; p<0,001], anne yaşının 35 üstü olması (OR 2,25, \%95 GA: 1,919-4,005; p=0,026) ve gestasyon haftasının 40 üstünde olması (OR 1,72,\%95 GA: 1,103-2,949; p=0,009) olarak bulundu.

Sonuç: Glikoz intoleransı olmadığı durumlarda makrozomik bebek sahibi olma ile ilişkili çeşitli faktörler bulunmaktadır. Makrozominin olası komplikasyonları açısından bu risk faktörleri bilinmelidir ve risk faktörlerine sahip anneler bilgilendirilmelidir.

\section{Introduction}

Fetal macrosomia is increasing in recent years and is a condition with heterogeneous etiologic factors (1). Zamorski and Biggs (2) reported the incidence of macrosomia in the general hospital population as $10 \%$. Many macrosomic infants are born without any risk factors and accurate prediction of macrosomia is not possible with only single risk factor. In a study comprising 75.363 newborns, the incidence was $8 \%$ in non-diabetic pregnancies and $26 \%$ in diabetic pregnancies (3). It is important that macrosomia is diagnosed prenatally to decide on mode of delivery and reduce natal and perinatal morbidity. The aim of this study was to research the characteristics of healthy mothers without diabetes with macrosomic infants.

\section{Materials and Methods}

\section{Study Design and Sample}

A case-control study was carried out including 291 healthy pregnant women from September 2013 to February 2014 who were followed-up and delivered in Mardin Women and Children Hospital. The study population comprised singleton live infants born full-term between 37-42 weeks, by spontaneous vaginal delivery or cesarean section without structural defects. Estimated by the date of last menstrual period, gestational age was confirmed by ultrasonographic measurements of crown-rump length and recorded as completed weeks. Two groups were determined in the study group; Group 1; birth weight less than $4.000 \mathrm{~g}$ and Group 2; birth weight above $4.000 \mathrm{~g}$. Data was collected by the same researcher who was trained in data collection. Data for newborns included gestational age at delivery, gender, weight, length, and head circumference. Pregnancy outcome data were extracted from the medical records. Characteristics of mothers that were recorded included maternal age, gravida and parity, pre-pregnant weight, height, gestational weeks at delivery, delivery mode, having previous macrosomic newborn, birth interval of previous live born infants, weight and height of the fathers. Complete blood count level before delivery and oral glucose tolerance test (OGTT) with $50 \mathrm{~g}$ which was screened at 24-28 weeks of pregnancy were obtained from medical records. While abortions were excluded, birth interval was measured at range instead. Socioeconomic status (SES) was defined as one of these three levels: "good, moderate, or bad" according to the mothers' perception. Fathers who smoked more than five cigarettes a day in the house were considered to be smokers. University Ethical Committee approval and required legal permissions were obtained and parents provided written informed consent for participation of their infants.

\section{Anthropometric Measurements and Body Mass Index}

Measurements of newborn including weight, height and head circumference and mothers' height and weight were taken by the same researcher (NB). Fathers' height and weight were reported by mothers. Newborns were weighed naked on the same digital scale. Mothers were weighed in their underwear, without external clothing and weight was measured at 37 weeks' gestation and gestational weight gain (GWG) was calculated. Height was measured flatlying in newborns and standing in mothers using the standard measurements. Pre-pregnancy weight was obtained from medical records. Pre-pregnancy body mass index (ppBMI) $\left(\mathrm{kg} / \mathrm{m}^{2}\right)$ was calculated and categorized into underweight $\left(<18.5 \mathrm{~kg} / \mathrm{m}^{2}\right)$, normal weight $\left(18.5-24.9 \mathrm{~kg} / \mathrm{m}^{2}\right)$, overweight $(25.0-29.9 \mathrm{~kg} /$ $\left.\mathrm{m}^{2}\right)$, and obese $\left(\geq 30.0 \mathrm{~kg} / \mathrm{m}^{2}\right)$. Macrosomic neonate was defined as an infant with a birth weight of more than $\geq 4.000 \mathrm{~g}$. 


\section{Exclusion Criteria}

Mothers with chronic diseases (including diabetes mellitus, hypertension, asthma, endocrine, metabolic, inflammatory diseases and hyperthyroidism), eclampsia, preeclampsia and oligo/polyhydramnios were excluded. Pregnant women who had an abnormal OGTT screening with $50 \mathrm{~g}$ glucose which was screened at 24-28 weeks of pregnancy -with serum glucose level $>140 \mathrm{mg} / \mathrm{dL}$ in the first hour of the testwere excluded. Pregnant women who were admitted to the hospital after the first trimester as their first visit during pregnancy and women who had previous small for gestational age infants were excluded. Smokers (before or during pregnancy) and people who filled out the questionnaire incompletely were excluded.

\section{Data Analysis}

Statistical analysis was performed using SPSS software, version 19.0. The variables were investigated using visual (histograms, probability plots) and analytical methods (KolmogorovSimirnov/Shapiro-Wilk's test) to determine whether or not they are normally distributed. Descriptive analyses are presented using mean, standard deviation, minimum, maximum values, frequency and percentage. Since the value of birth weight was normally distributed, the independent samples $\mathrm{T}$ test was conducted to compare the groups. The Chisquare test was used to compare categorical variables between the groups. A p-value of less than 0.05 was considered to show a statistically significant result. For the multivariate analysis, the possible factors identified by univariate analysis were further entered into the logistic regression analysis to determine independent predictors of birth weight. HosmerLemeshow goodness of fit statistics was used to assess model fit. A 5\% type-I error level was used to infer statistical significance. For logistic regression analysis the stepwise (Backward: LR) method was used. The goodness of fit of the logistic model was evaluated with the Hosmer and Lemeshow Test. This test identified a $\mathrm{p}$ value of 0.953 , indicating high goodness of fit of the model. The Nagelkerke R Square value of the model was determined as 0.217 and Cox\&Snell $\mathrm{R}$ Square value of the model was determined as 0.162 .

\section{Results}

The characteristics of mothers and children are summarized in Tables 1, 2, 3 .

A positive correlation was found between birth weight and gestational week at birth as shown in Figure $1(\mathrm{r}=0.460 ; \mathrm{p}<0.001)$.

There was no correlation between birth weight of children and mothers' age in our study group $(\mathrm{r}=0.107$; $\mathrm{p}=0.068$ ). While $55.6 \%$ of patients were older than 35 years and had previous births to macrosomic infants, $44.4 \%$ had infants with birth weight below $4.000 \mathrm{~g}$.

A positive correlation was found between ppBMI value and birth weight of the newborn in our study group ( $\mathrm{r}=0.152 ; \mathrm{p}=0.010)$ as shown in Figure 2.

The use of multivitamins, folic acid and iron supplements during pregnancy was shown not to be a statistically significant factor for birth weight between the groups $(\mathrm{p}>0.05)$.

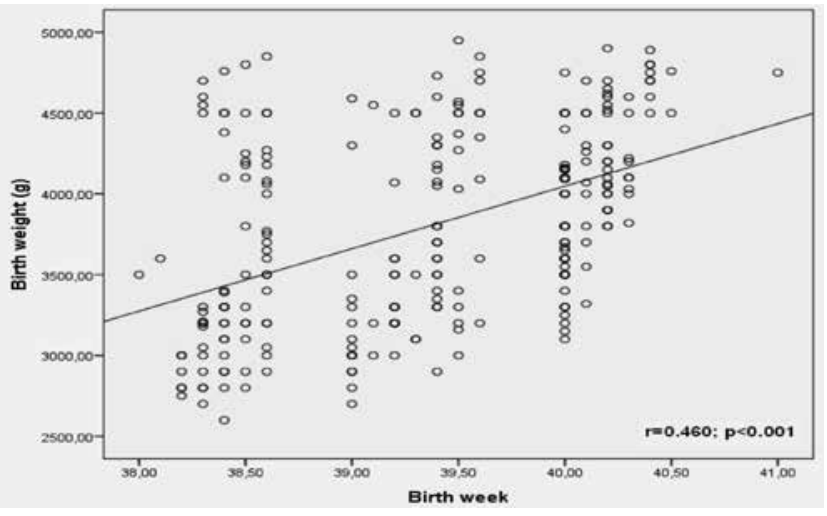

Figure 1. Correlation between birth weight and birth week of the children

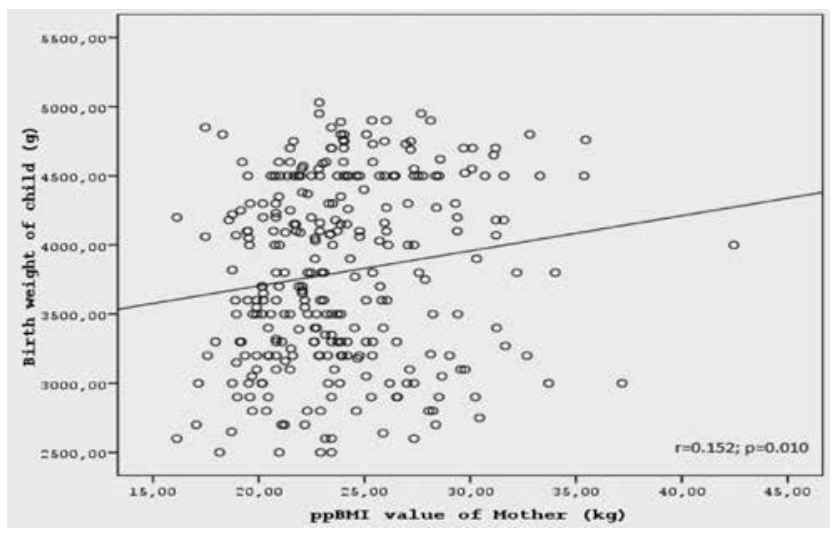

Figure 2. Correlation between birth weight and mother's prepregnancy body mass index value in our study group ppBMI: Pre-pregnancy body mass index 
Results of the Multivariate Analyses

According to univariate analysis results to calculate the OR values for dependent variables thought to be risk factors affecting birth weight, logistic regression analysis was completed. For logistic regression analysis, the independent variables included were gestational age, gender, maternal age, ppBMI, weight gain during pregnancy, parity and SES.

Table 1. Characteristics of newborn in the groups

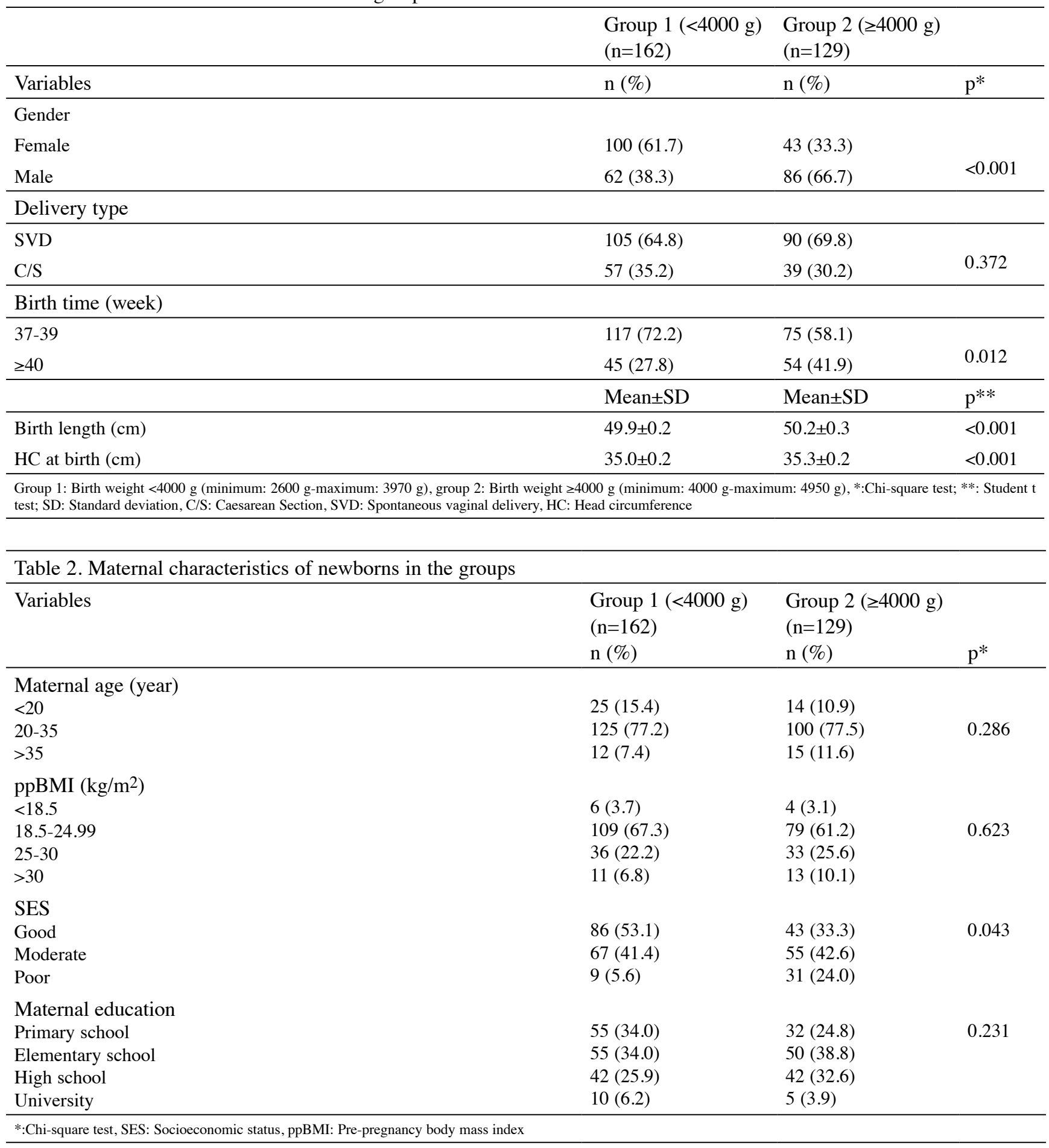


According to logistic regression analysis, variables of gender, maternal age and gestational week of pregnancy were identified as risk factors affecting birth weight (Table 4).

The results of logistic regression analysis showed the risk of having a macrosomic infant was increased for; male infant [odds ratio (OR): 3.39; $95 \%$ confidence interval (CI): 2.010-5.211; $\mathrm{p}<0.001]$, maternal age above 35 years (OR: 2.25; 95\% CI: 1.919-4.005; $\mathrm{p}=0.026)$ and gestational week more than 40 weeks (OR: 1.72; 95\% CI: 1.103-2.949; $\mathrm{p}=0.009$ ).

Gender is an important risk factor for macrosomia, using this parameter alone; the risk of macrosomia can be predicted with $61.7 \%$ sensitivity and $66.7 \%$ specificity. When maternal age and gestational week are included in the model with gender, the sensitivity and specificity values were found to be $85.2 \%$ and $37.2 \%$, respectively. It was observed that as other affecting factors are included in the logistic model with gender, the sensitivity increases but the specificity decreases.

When risk factors relating to the father are investigated in group 1, the rate of fathers who smoke was $59.3 \%$ while in the macrosomic group this rate was $50.4 \%(\mathrm{p}=0.130)$. When all cases in the study groups were evaluated, there was no statistically significant difference between the birth weight of infants of fathers who were smokers or non-smokers $(\mathrm{p}=0.425)$.

\section{Discussion}

In the present study, macrosomia may be predicted with the presence of the following risk factors;

Table 3. Obstetrics characteristics of mothers in the groups

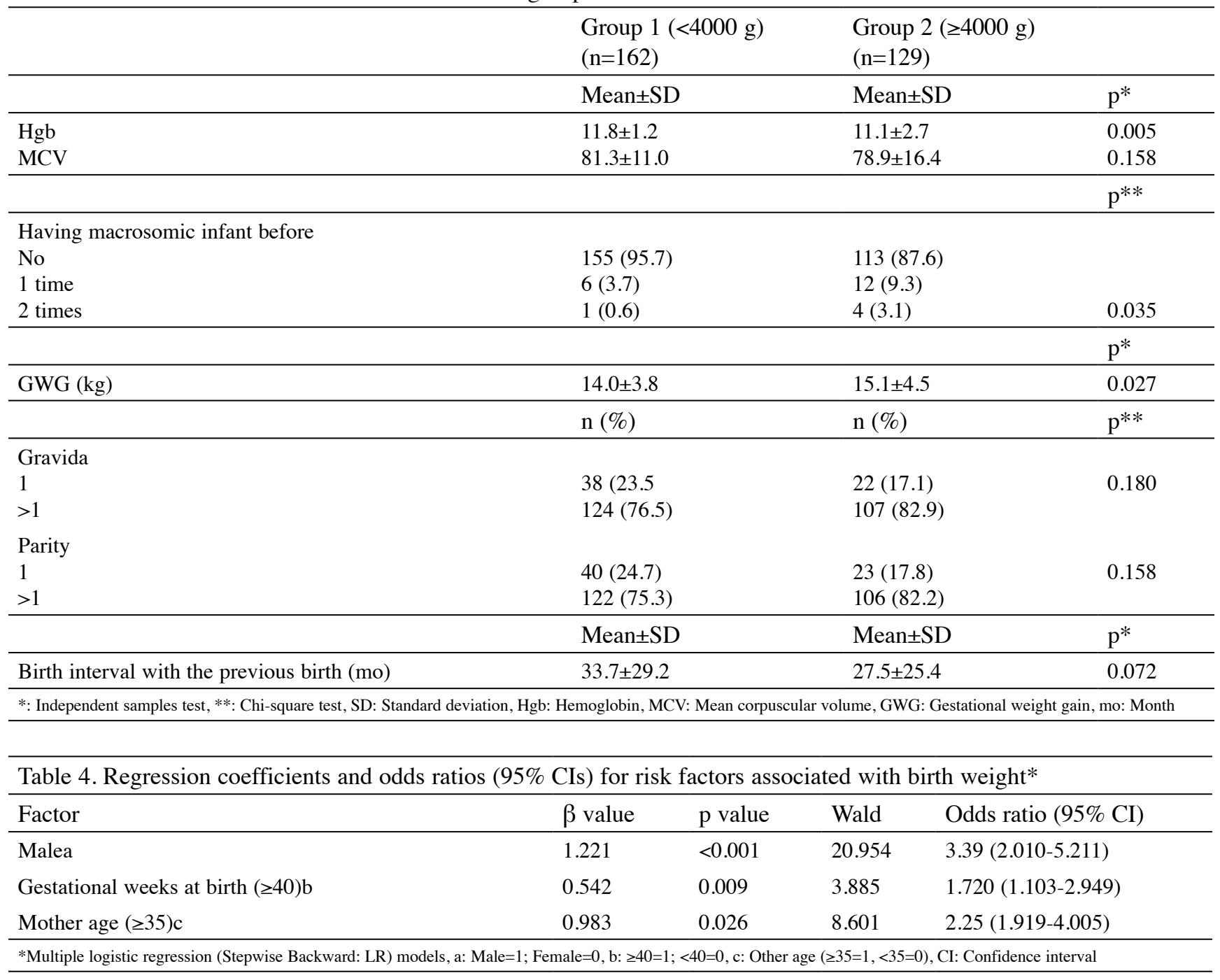


previous delivery of an infant weighing $\geq 4.000 \mathrm{~g}$, advanced gestational age, higher weight gain during pregnancy, gender of neonate and SES.

Maternal age above 35 years was found to be a risk factor for macrosomia at the level of 3 times (4). Kadanalı et al. (5) also found association between newborn anthropometry and maternal age. In this study; although there was no correlation between birth weight of children and mothers' age; the mothers less than 20 years of age and above 35 years of age were more common in the macrosomic group.

Globally, especially in the west, the increasing rate of obesity is an important public health concern where $11 \%$ of pregnant women are obese and $28 \%$ are overweight (6). The risk of macrosomia has been shown to increase with ppBMI in previous studies (7). The current guidelines, recommended by the Institute of Medicine (IOM) to limit negative pregnancy outcomes, provide ranges of GWG based on ppBMI (8). The risk of having a weightier infant was strongly increased in women who exceeded the IOM 2009 GWG guidelines. A positive correlation was found between ppBMI value and birth weight of the newborn in our study group and GWG was higher in the macrosomic group. On the other hand, the effect of maternal underweight on obstetric performance is less clear. In this retrospective analysis, there was an insufficient number of underweight women or women with low GWG.

Mothers who previously gave birth to an infant weighing over $4.000 \mathrm{~g}$ were found to have a 5 to 10 times higher rate of having a subsequent infant above $4.500 \mathrm{~g}$, compared to control group $(9,10)$. In this study, women who had a macrosomic infant previously had a high rate of having macrosomic infant again.

The macrosomia rate was found to be 3-7 times higher in post-term infants compared to term infants (11). Spellacy et al. (11) found the macrosomia rate to be $10.8 \%$ in post-term infants and Berard et al. (12) found this rate to be $17 \%$. Similarly; in this study a positive correlation was found between birth weight and gestational week at birth.

Previous studies showed that macrosomia resulted more in cesarean deliveries $(13,14)$. Induction of labor may reduce the risk of cesarean delivery with known birth weight. The incidence of cesarean section was not increased in our study group. There was no birth weight above 5.000 grams in our study which may explain low cesarean section needs. Additionally, this may also be due to higher rate of macrosomic newborn in lower-income families.

A range of good health outcomes are positively correlated with SES. There was no relationship found between high birth weight and SES in a report by Cesur and Kelly (15). The effects of factors relating to SES on the chances of having a macrosomic infant have been examined in a few studies (16). The present study showed that the macrosomia rate was higher in low-income families. However, GWG was also higher in this group. This may be the result of anxiety of possibly having a low-birth weight newborn that could lead to overfeeding. Hemoglobin value was also found to be lower in the macrosomic group which was thought to be linked to lack of variety of nutrition that may be due to lower SES.

The risk of macrosomia in multiparous women has been shown to be 2-3 times higher than that in control group in the majority of studies (2). The rate of macrosomia was $78 \%$ in multiparous women according to Berard et al. (12). Whether multiparity is an independent risk factor or is dependent on other factors such as age has not been determined. In this study in the macrosomic group, the number of multigravida and multiparity was higher though not statistically significant. In addition, $55.6 \%$ of patients were older than 35 years and $44.4 \%$ of those with a history of previous macrosomic infants had infants with birth weight below $4.000 \mathrm{~g}$.

At any gestational age, male infants are heavier than female infants, and 60-70\% of macrosomic infants are males $(2,5)$. Similarly; in this study, in the macrosomic group, the number of male infants was significantly higher.

Approximately half of the variance in birth weight is explained by maternal factors, while no significant effect is found from paternal factors (17). It has been shown that paternal BMI can affect growth of the male newborn (18). Neither paternal BMI nor paternal smoking was found to have effect on macrosomia in this study.

\section{Conclusion}

In conclusion, the findings of this study advance our understanding of the factors behind having a macrosomic infant in the absence of glucose intolerance and confirm 
the effects of previous delivery of an infant weighing $\geq 4.000 \mathrm{~g}$, advanced gestational week at birth, higher weight gain during pregnancy, male gender of neonate and low SES. Studies examining eating attitudes of pregnant women are also needed to refine this topic.

\section{Ethics}

Ethics Committee Approval: Committee approval was obtained, Informed Consent: Consent form was filled out by all participants.

Peer-review: External and Internal peer-reviewed.

\section{Authorship Contributions}

Surgical and Medical Practices: Nazan Kaymaz, Sibel Cevizci, Sule Yıldırım, Concept: Nazan Kaymaz, Hakan Aylanç, Nurcan Bulur, Design: Nazan Kaymaz, Naci Topaloğlu, Meryem Gencer, Data collection or Processing: Nazan Kaymaz, Nurcan Bulur, Fatih Köksal Binnetoğlu, Mustafa Tekin, Analysis or Interpretation: Nazan Kaymaz, Sibel Cevizci, Fatih Battal, Literature Search: Nazan Kaymaz, Emine Coşar, Şule Yuldırım, Writing: Nazan Kaymaz, Şule Yildirım.

Conflict of Interest: No conflict of interest was declared by the authors.

Financial Disclosure: The authors declared that this study received no financial support.

\section{References}

1. Langer O. Prevention of macrosomia. Baillieres Clin Obstet Gynaecol 1991;5:333-47.

2. Zamorski MA, Biggs WS. Management of suspected fetal macrosomia. Am Fam Physician 2001;63:302-6.

3. Langer O, Kozlowski S, Brustman L. Abnormal growth patterns in diabetes in pregnancy: a longitudinal study. Isr J Med Sci 1991;27:516-23.
4. Oral E, Cağdaş A, Gezer A, Kaleli S, Aydinli K, Oçer F. Perinatal and maternal outcomes of fetal macrosomia. Eur J Obstet Gynecol Reprod Biol 2001;99:167-71.

5. Kadanalı S, Önvural A, Erten O. Doğum kilosunu etkileyen faktörler. Perinatoloji Dergisi 1994;2:89-93.

6. Bhattacharya S, Campbell DM, Liston WA, Bhattacharya S. Effect of Body Mass Index on pregnancy outcomes in nulliparous women delivering singleton babies. BMC Public Health 2007;7:168.

7. Yanıkkerem E, Mutlu S. Maternal Obesity: consequences and prevention strategies. TAF Prev Med Bull 2012;11: 353-64.

8. Schieve LA, Cogswell ME, Scanlon KS. An empiric evaluation of the Institute of Medicine's pregnancy weight gain guidelines by race. Obstet Gynecol 1998;91:878-84.

9. Lazer S, Biale Y, Mazor M, Lewenthal H, Insier V. Complications associated with the macrosomic fetus. J Reprod Med 1986;31:501-5.

10. Okun N, Verma A, Mitchell BF, Flowerdew G. Relative importance of maternal constitutional factors and glucose intolarence of pregnancy in the development of newborn macrosomia. J Matern Fetal Med 1997;6:285-90.

11. Spellacy WN, Miller S, Winegar A, Peterson PQ. Macrosomia-maternal characteristics and infant complications. Obstet Gynecol 1985;66:158-61.

12. Berard J, Dufour P, Vinatier D, Subtil D, Vanderstichele S, Monnier JC, et al. Fetal macrosomia: risk factors and outcome. A study of the outcome concerning 100 cases $>4500$. Eur J Obstet Gynecol Reprod Biol 1998;77:51-9.

13. Sinclair BA, Rowan JA, Hainsworth OT. Macrosomic infants are not all equal. Aust N Z J Obstet Gynaecol 2007;47:101-5.

14. Tsai YL, Chong KM, Seow KM. Following the 2009 American Institute of Medicine recommendations for normal body mass index and overweight women led to an increased risk of fetal macrosomia among Taiwanese women. Taiwan J Obstet Gynecol 2013;52:341-6.

15. Cesur R, Kelly IR. From cradle to classroom: high birth weight and cognitive outcomes. Forum Health Econ Policy 2010;13:1558-9544.

16. Rachel Webb. High Birth Weight and Socio-Economic Status University of Canterbury.

17. Lepercq J, Timsit J, Hauguel-de Mouzon S. Etiopathogeny of fetal macrosomia. J Gynecol Obstet Biol Reprod (Paris) 2000;29(Suppl 1):6-12.

18. Chen YP, Xiao XM, Li J, Reichetzeder C, Wang ZN, Hocher B. Paternal body mass index (BMI) is associated with offspring intrauterine growth in a gender dependent manner. PLoS One 2012;7:36329. 